\title{
Editor's Report for Volume 120 (2006)
}

Mailing dates for issues in volume 120(1) 15 July 2007, (2) 1 November 2007; (3) 30 November 2007; (4) 31 December 2007.

A summary of circulation to members and subscribers (institutional and individual) totals for 2006 is given in Table 1. The number of articles and notes in volume 121 is summarized in Table 2 by topic; totals for Book Reviews and New Titles are given in Table 3, and the distribution of content by page totals per issue in Table 4.

Council continued to authorize $40 \%$ of membership dues for publication of the journal and all of subscriptions (both individual and institutional). Council also has allocated $80 \%$ of the annual interest from the Manning Fund and other capital funds to The Canadian Field-Naturalist. Use of the Manning fund portion was broadened on an issue-by-issue basis to offset the publication costs where authors lacked grant or institutional funds to support publication.

The journal was printed at Gilmore Printers, Ottawa, and thanks are due business representative Tom Smith; customer representative Chuck Graham for overseeing production, and Wendy Cotie for typesetting and corrections. Leslie Cody prepared the Index for volume 120; Elizabeth Morton proofed the galleys. When Bill Cody, Businesss Manager for 60 years, was unable to carry on, most of his duties were shouldered by Treasurer Frank Pope and Assistant Treasurer Jim Ward with invoice preparation assumed by the editor. Roy John arranged and edited book reviews and prepared the New Titles listings. Special thanks are due to Jenifer Penny, Program Botanist, B.C. Conservation Data Centre, Victoria, British Columbia, for editing and revising for 120(1) the eight papers on conservation evaluation of some British Columbia plants originated by the late George Douglas and also for preparing the tribute and updated bibliography for Douglas. The journal con-
TABLE 2. Number of articles and notes published in The Canadian Field-Naturalist Volume 120 (2006) by major field of study.

\begin{tabular}{lrcr}
\hline \hline Subject & Articles & Notes & Total \\
\hline Mammals & 22 & 6 & 28 \\
Birds & 8 & 5 & 13 \\
Amphibians + reptiles & 1 & 1 & 2 \\
Fish & 5 & 3 & 8 \\
Insects & 3 & 0 & 3 \\
Other invertebrates & 1 & 1 & 2 \\
Plants & 13 & 0 & 13 \\
Paleontology & 1 & 0 & 1 \\
Tributes & 2 & 0 & 2 \\
\hline Totals & 56 & 16 & 72 \\
\hline \hline
\end{tabular}

tents and abstracts are now posted on the Ottawa FieldNaturalists' Club website by webmaster Sandra Garland, and PDFs may be ordered by authors as well as traditional print reprints.

Manuscripts (excluding book reviews, notices, and reports) submitted to The Canadian Field-Naturalist totalled 67 in 2006, down by 8 from the total for 2005 . The following reviewed for papers submitted in 2006 (with number of manuscripts reviewed in parentheses if more than one):

Associate Editors: R. Anderson, Canadian Museum of Nature, Ottawa, Ontario; C. D. Bird, Erskine, Alberta (8); R. R. Campbell, St. Albert, Ontario (2); P. M. Catling, Agriculture and Agri-food Canada, Ottawa, Ontario (5); B. W. Coad, Canadian Museum of Nature, Ottawa, Ontario (6); A. J. Erskine, Sackville, New Brunswick (10); D. F. McAlpine, New Brunswick Museum, Saint John, New Brunswick (4); D. W. Nagorsen, Mammalia Biological Consulting, Victoria, British Columbia (8); W. O. Pruitt, Jr., University of Manitoba, Winnipeg, Manitoba (6).

TABLe 1. The 2006 circulation of The Canadian Field-Naturalist (2005 in parentheses). Prepared by Robin Murphy, bmr group, Ottawa. Totals are copies mailed. As some members opt not to receive the journal, membership total here is only those receiving the journal. For total club membership see the Annual Report of the membership committee to the 2007 Annual Business Meeting.

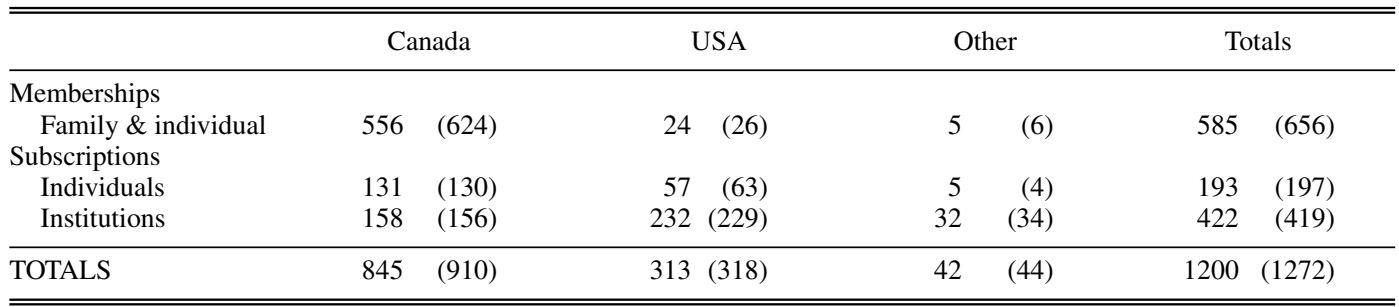

Note: 20 countries (outside Canada and United States) are included under "Other" (number of copies in parentheses): Australia, Austria, Belgium, Brazil, Denmark, United Kingdom (9: including 1 to Scotland), Finland (2), France (2), Germany (2), Iceland, Ireland, Japan, Netherlands (2), New Zealand, Norway (6), Poland, Russia, South Africa, Spain (2), Switzerland, Taiwan (2). 
TABLE 3. Number of reviews and new titles published in Book Review section of The Canadian Field-Naturalist Volume 120 (2006) by topic.

\begin{tabular}{lcc}
\hline \hline & Reviews & New Titles \\
\hline Zoology & 37 & 126 \\
Botany & 4 & 15 \\
Environment & 9 & 58 \\
Miscellaneous & 10 & 4 \\
Young Naturalists & 1 & 5 \\
\hline Totals & 61 & 208 \\
\hline \hline
\end{tabular}

Other Reviewers: P. Achuff, Waterton Lakes, Alberta; W. B. Ballard, Texas Tech University, Lubbock, Texas (4); J. R. Bider, Baie d'Urfe, Quebec (2); G. Blouin-Demers, University of Ottawa, Ontario; E. L. Bousfield, Victoria, British Columbia (2); K. Conlan, Canadian Museum of Nature, Ottawa (2); D. Boyd, Helena, Montana; R. J. Brooks, University of Guelph, Ontario; S. Carriere, Environment and Natural Resources, Yellowknife, Northwest Territories; R. W. Campbell, Biodiversity Centre for Wildlife Studies, Victoria, British Columbia; J. A. Cook, Museum of Southwestern Biology, University of New Mexico, Albuquerque; S. Cooke, Carleton University, Ottawa, Ontario (2); W. J. Crins, Ontario Ministry of Natural Resources, Peterborough, Ontario; D. B. Donald, Environment Canada, Regina, Saskatchewan; J. Dubois, Manitoba Natural Resources, Winnipeg, Manitoba; J. Ferron, Universite du Quebec a Rimouski, Quebec; D. R. Galbraith, Royal Botanical Gardens, Hamilton, Ontario; A. J. Gaston, Environment Canada, Gatineau, Quebec; D. Giblin, Burke Museum, University of Washington, Seattle, Washington; J. Gilhen, Nova Scotia Museum of Natural History, Halifax, Nova Scotia (2); P. Goossen, Environment Canada, Edmonton, Alberta; P. T. Gregory, University of Victoria, British Columbia; F. H. Harrington, Mt. St. Vincent University, Halifax, Nova Scotia; S. J. Hecnar, Lakehead University, Thunder Bay, Ontario; E. Hendrycks, Canadian Museum of Nature, Ottawa, Ontario; P. Hicklin, Environment Canada, Sackville, New Brunswick; L. V. Hills, Cochrane, Alberta; S. Hooker, University of St. Andrews, Fife, United Kingdom; B. D. Johnson, Herbarium, Northern Forest Research Centre, Canadian Forest Service, Edmonton, Alberta (2); C. S. Houston, Saskatoon, Saskatchewan; J. Kamler, Polish Academy of Sciences, Bialowieza, Poland; C. R. Lacroix, University of Prince Edward Island, Charlottetown; J. Lanteigne, Travaux publics et services, gouvernementaux Canada, Gatineau, Quebec; G. Lee, Ottawa, Ontario; R. MacCulloch, Royal Ontario Museum, Toronto, Ontario; J. Madill, Canadian Museum of Nature, Ottawa, Ontario; F. F. Mallory, Laurentian University, Sudbury, Ontario (2); M. Mallory, Environment Canada, Iqaluit, Nunavut; André Martel, Canadian Museum of Nature, Ottawa, Ontario; L. D. Mech, U.S. Geological Survey, The Raptor Center, University of Minnesota, St. Paul (3); J. Metcalfe-Smith, Aquatic Ecosystem Protection Branch, National Water Research Institute, Burlington, Ontario; A. Moehrenschlager, Calgary Zoological Society, Alberta; E. L. Mills, Dalhousie University, Halifax, Nova Scotia; G. Morrison, Environment Canada, Gatineau. Quebec; G. Parker, Environment Canada, Sackville, New Brunswick; E. Pip, University of Winnipeg, Manitoba; G. Pohle, Huntsman Marine Science Centre, St. Andrews, New Brunswick; W. Preston, Winnipeg, Manitoba; G. Proulx, Alpha Research \& Management Ltd., Sherwood
TABLE 4. Number of pages per section published in The Canadian Field-Naturalist Volume 120 (2006) by issue.

\begin{tabular}{lrrrrr}
\hline \hline & $(1)$ & $(2)$ & $(3)$ & $(4)$ & Total \\
\hline Articles & 105 & 85 & 104 & 68 & 362 \\
Notes & 7 & 11 & 3 & 12 & 33 \\
Tributes & 0 & 12 & 9 & 0 & 21 \\
Book Reviews* & 19 & 15 & 13 & 19 & 66 \\
CFN/OFNC Reports** & 00 & 2 & 9 & 5 & 16 \\
News and Comment & 2 & 2 & 1 & 2 & 7 \\
Index & 0 & 0 & 0 & 21 & 21 \\
Advice to Contributors & 1 & 1 & 1 & 1 & 4 \\
\hline Totals & 134 & 128 & 140 & 128 & 530 \\
\hline \hline
\end{tabular}

* Total pages for book review section include both reviews and new titles listings.

*** Includes CFN Editor's report in (2), OFNC Annual Business Meeting (3) and OFNC Awards (4).

Park, Alberta (2); R. Reeves, Okapi Wildlife Associates, Hudson, Quebec (2); T. E. Reimchen, University of British Columbia, Victoria, British Columbia; G. J. Robertson, Environment Canada, Mount Pearl, Newfoundland; L. Rogers, Ely, Minnesota; R. Rosatte, Ministry of Natural Resources, Trent University, Peterborough, Ontario; A. Russell, University of Calgary, Calgary, Alberta; F. Scott, Acadia University, Wolfville, Nova Scotia; F. W. Schueler, Bishops Mills Natural History Center, Oxford Mills, Ontario; J. W. Sheard, University of Saskatchewan, Saskatoon; Brian Slough, Whitehorse, Yukon Territory; K. W. Stewart, University of Manitoba, Winnipeg, Manitoba (3); P. Weatherhead, Queen's Biological Station, Elgin, Ontario; M. J. Wetzell, Illinois, Natural History Survey, Champaign, Illinois; N. Yan, York University, North York, Ontario.

I am also indebted once again to the President of the Ottawa Field-Naturalists' Club, Gary McNulty, and the Club Council for continuing support of the journal; Chairman Ron Bedford and the Publications Committee of the OFNC for editorial encouragement and support, the Finance Committee for input and encouragement to speed things up, the Canadian Museum of Nature for access to its library and the facilities at the Natural Heritage Building, 1740 Pink Road, Aylmer, Quebec, and to Joyce for everything else.

I must add my special thanks due William J. (Bill) Cody who served the club as council member for more than 60 years, vitually all ot this time as Business Manager of The Canadian Field-Naturalist. Those of us exposed to Bill's unfailing good humour, determination, efficient focus on the job on hand, and sometimes his inevitable serenades, have lasting memories of the time shared. Bill served with, and kept each on track, five editors (one twice) - Harold Senn to 1955), Bob Hamilton (1956-1961), myself (1962-1966), Ted Mosquin (1967-1972), Lorraine Smith (1972-1981, and me again (1981 — present). Efficient management and financial stability through good times and bad were due in large measure to Bill's initiative which assured, in some periods, the journals very survival. 
A decade ago, to mark 50 years of service, the club paid tribute to Bill's contribution to that point with a reception at the Central Experimental Farm, Department of Agriculture, Ottawa, where Bill had spent his whole career, including "retirement", as a research botanist. Stephen Darbyshire for Awards Committee stated in part (1998. Canadian Field-Naturalist 112(4): 719-720):

"Such long-term service and dedication is unprecedented in the history of the Club and is not likely to ever be repeated. The titles of office do not reveal the extent to which Bill has laboured for the Club. One cannot completely list the jobs that he has taken on (even Bill cannot remember them all), many of which are among the most distasteful and time consuming (imagine the years of dealing with government forms for postage rates, charitable status, etc.). Executive officers have come and gone, Canadian Field-Naturalist editors have come and gone, Council is re-elected every year, but Bill Cody continues as a major constituent of the glue that keeps the Club together and keeps it, and its scientific publication, running smoothly."

Bill continued to perform these duties for close to another decade before failing health forced him pass them on to others. The full truth in the earlier words of tribute has become increasingly realized by those of us Bill left to share his multitude of tasks. Most of the burden has fallen on Frank Pope, already contributing tremendous service as Treasurer of the Ottawa Field-Naturalist's Club, and Jim Ward as Treasurer's Assistant. They have made the transition work.

FRANCIS R. COOK Editor 